\title{
Short communication: Effects of milking frequency on udder morphology, milk partitioning, and milk quality in 3 dairy goat breeds
}

\author{
A. Torres, ${ }^{*}$ N. Castro, $†$ L. E. Hernández-Castellano, $†$ A. Argüello, $\dagger^{1}$ and J. Capote* \\ *Instituto Canario de Investigaciones Agrarias, La Laguna, Tenerife 38200, Spain \\ †Department of Animal Science, Universidad de Las Palmas de Gran Canaria, 35413 Arucas, Spain
}

\begin{abstract}
Thirty-six dairy goats of 3 breeds (Majorera, Tinerfeña, and Palmera) in mid lactation (124 $\pm 8 \mathrm{~d}$ in milk) were subjected unilaterally to once $(\times 1)$ or twice daily milking $(\times 2)$ for 5 wk to evaluate udder morphology, milk partitioning, and somatic cell count. Majorera and Palmera goats presented the highest and lowest udder depth values, respectively, whereas the differences between initial and final cistern-floor and teat-floor distances were not affected by milking frequency or breed factors. Cisternal and alveolar milk percentages were similar between $\times 1$ and $\times 2$ in the studied breeds. Milking frequency did not affect milk composition in the cisternal fraction, suggesting a greater transfer of milk from the alveoli to the cistern during early udder filling. However, milking frequency caused diverse changes in the milk composition in the alveolar fraction, especially in fat, lactose, and total solids contents. No udder halves presented clinical mastitis during the experimental period, suggesting that $\times 1$ does not impair udder health and indicating that the studied breeds are adapted to this milking frequency.
\end{abstract}

Key words: milking frequency, milk partitioning, milk quality, dairy goat

\section{Short Communication}

Intramammary filling rate and cisternal capacity to store milk determine the choice of an adequate milking routine. Overfilling of the udder increases intramammary pressure and distention of the alveoli, which can compromise subsequent milk synthesis as has been reported by Peaker (1980). Animals with large cisterns are milked faster with simplified routines and are better at tolerating extended milking intervals (Knight and Dewhurst, 1994; Ayadi et al., 2003; Salama et al., 2003).

Techniques for determining cisternal and alveolar milk fractions have been improved and include the

Received February 15, 2012.

Accepted October 26, 2012.

${ }^{1}$ Corresponding author: aarguello@dpat.ulpgc.es use of an oxytocin receptor antagonist to block spontaneous milk ejection (Wellnitz et al., 1999), allowing a reliable separation between both fractions. This is important because the udder morphology of some dairy goat breeds (e.g., Tinerfeña breed) is characterized by higher teat-floor distance (TF) than cistern-floor distance $(\mathbf{C F})$, a negative circumstance that makes more difficult the emptying of cisternal milk by gravity (López et al., 1999).

The aim of the present study was to determine the effects of milking frequency on udder morphology, milk partitioning, composition of each fraction, and SCC of 3 dairy goat breeds (Majorera, Tinerfeña, and Palmera).

The present study was performed on the experimental farm of the Instituto Canario de Investigaciones Agrarias in Tenerife (Spain) on 36 dairy goats belonging to 3 different breeds: Majorera $(\mathrm{n}=12)$, Tinerfeña $(\mathrm{n}=$ $12)$, and Palmera $(\mathrm{n}=12)$. The experimental animal procedures were approved by the Ethical Committee of the Universidad de Las Palmas de Gran Canaria (Arucas, Spain). Goats with symmetrical udder halves were in third parity with $124 \pm 8$ DIM at the beginning of the experiment. The milking frequency before the start of the experimental period was once per day. During a 5-wk period, each goat was milked once daily in the left mammary gland $(\times \mathbf{1}$; at $0700 \mathrm{~h})$, whereas the right mammary gland was milked twice daily $(\times \mathbf{2}$; at 0700 and $1700 \mathrm{~h}$ ). The animals were fed with commercial concentrate, maize, lucerne, wheat straw, and a vitamin-mineral corrector in accordance with the guidelines issued for lactating goats by Institut National de la Recherche Agronomique (INRA, Paris, France; Jarrige, 1990). Goats were milked in a double 12-stall parallel milking parlor (Alfa Laval Iberia SA, Madrid, Spain) equipped with recording jars $(4 \mathrm{~L} \pm 5 \%)$ and a low-line milk pipeline. Milking was performed at a vacuum pressure of $42 \mathrm{kPa}$, a pulsation rate of 90 pulses/min, and a pulsation ratio of 60/40, in accordance with Capote et al. (2006). The milking routine included wiping dirt off teat ends and stripping 2 to 3 squirts of milk from each teat; machine milking and stripping milking, done by the operator to remove the milk remaining in the udder before cluster removal; and teat dipping in an 
iodine solution (P3-cide plus; Henkel Hygiene, Barcelona, Spain).

Milk recording and sampling were done at wk 1, 3, and 5. Before the experiment, the goats were exposed to 3 wk of adaptation. In the first and second weeks, the goats began to enter the milking parlor in the afternoon, but the goats were not milked. During the third week of adaptation, the goats were milked once and twice daily in the left and right mammary gland, respectively, but the milk was not collected. Udder measurements of each goat were taken just before the first and the last milking of the experimental period. The following udder measurements were performed: $\mathrm{CF}$ and $\mathrm{TF}$, recorded as the differences between initial and final measurements $(\Delta \mathbf{C F}$ and $\Delta \mathbf{T F})$, and udder depth (UD), recorded as the difference in distance between the udder floor and the cistern floor.

Before the a.m. milking (24- and 14-h milking intervals for $\times 1$ and $\times 2$, respectively) on the sampling days, each goat was injected intravenously with $0.8 \mathrm{mg}$ of an oxytocin receptor blocking agent (Tractocile; Ferring SAU, Madrid, Spain) inside a pen immediately before entering the parlor to record cisternal milk volume. After cisternal milk removal, the goats were injected intravenously with 2 IU of oxytocin (Oxiton; Laboratorios Ovejero, León, Spain) to reestablish milk ejection to allow the measurement of alveolar milk. Cisternal and alveolar milk volumes were recorded by using the recording jars in the milking parlor and milk samples were collected separately for each udder half and fraction.

Milk samples (cisternal and alveolar fractions) were analyzed immediately after collection to determine milk composition and SCC. Protein, fat, lactose, TS, and SNF percentages were determined using a MilkoScan 133 analyzer (Foss Electric A/S, Hillerød, Denmark), and SCC using a Fossomatic 90 cell counter (Foss Electric A/S). Somatic cell count was calculated by a weighted average of the cisternal and alveolar SCC.

The statistical analysis used to evaluate the effects of breed and milking frequency on morphological parameters of udder, milk partitioning and SCC was PROC MIXED of SAS (version 9.0; SAS Institute Inc., Cary, NC). The model included fixed effects of milking frequency $(\times 1$ or $\times 2)$ and breed (Majorera, Tinerfeña, or Palmera) and their interactions. The repeated statement was used to take into account repeated measures for each individual animal. Differences among the breeds and milking frequencies were evaluated using a multiple comparison test following the Tukey-Kramer method. Statistical differences were considered significant at $P<0.05$. Data are presented as least squares means.
The $\triangle \mathrm{CF}$ and $\Delta \mathrm{TF}$ (Table 1 ) did not differ due to milking frequency or breed $(P>0.05)$. Knight and Dewhurst (1994) found that large cisternal size may explain the small negative effects of longer milking intervals on udder morphology because it is better prepared to accommodate greater milk accumulation, and may explain the absence of differences in the cistern descent of goat udders.

Majorera and Palmera goats presented the highest and lowest UD values, respectively (Table 1). The increase in UD values during the experimental period can be explained because $\Delta \mathrm{TF}$ were lower than $\Delta \mathrm{CF}$, which implies that increasing the cistern depth increases the UD. The cistern depth is a consequence of teat placement of the studied goats whose teats are not located in the ventral portion of the udder (Capote et al., 2006).

Cisternal and alveolar milk percentages were similar between $\times 1$ (24 h after milking) and $\times 2(14 \mathrm{~h}$ after milking) in Majorera, Tinerfeña, and Palmera breeds (Table 1). Salama et al. (2004) did not find differences in cisternal milk fraction in Murciano-Granadina goats between $\times 1$ and $\times 2$ when milking intervals were 16 and $24 \mathrm{~h}$ (values ranged from 66 to $76 \%$ ). The differences observed in the cisternal and alveolar fractions between breeds may be explained by the cisternal size, because greater cisterns are able to store more milk. Bruckmaier et al. (1997) explained that a large absolute cisternal volume implies that a large fraction of the milk is stored within the cisternal cavities and it varies according to breed.

Percentages of cisternal milk components (Table 1) were not affected by milking frequency $(P>0.05)$. This absence of differences between $\times 1$ and $\times 2$ goats might be due to the fact that approximately $80 \%$ of total milk was stored in the cisternal compartment and most of the transfer of milk from the alveoli and small milk ducts had already taken place. However, McKusick et al. (2002) observed marked differences in milk fat percentage in the cisternal fraction between different milking intervals in dairy ewes, in which the cistern was only capable of storing approximately $50 \%$ of the total milk volume, being more susceptible to changes in the transfer of milk components.

Alveolar milk of $\times 1$ goats contained higher percentages of fat and TS than alveolar milk of $\times 2$ goats, but these differences were significant only in the Majorera breed. McKusick et al. (2002) explained that a transfer of milk fat from the alveoli to the cistern occurs during early udder filling; however, this transfer no longer takes place during later intervals, resulting in an accumulation of milk fat in the alveolar compartment. Alveolar milk was richer in fat content than cisternal milk in all breeds and milking intervals, which agrees 
Table 1. Morphological parameters of udder, milk partitioning, milk composition, and SCC of 3 dairy goat breeds milked once $(\times 1)$ or twice $(\times 2)$ daily ${ }^{1,2}$

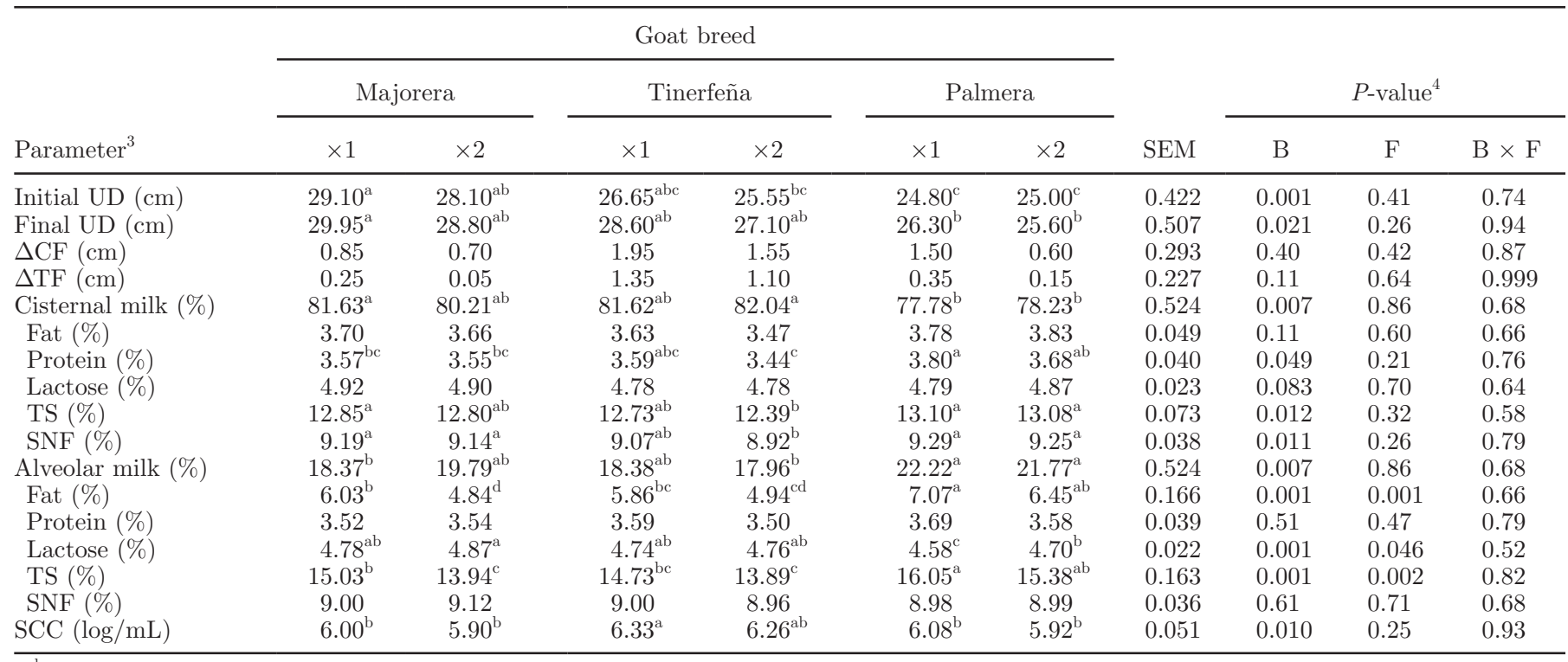

${ }^{\mathrm{a}-\mathrm{d}}$ Means with different superscripts within the same row are different $(P<0.05)$.

${ }^{1}$ Data are least squares means and standard error of means.

${ }^{2}$ Morphological parameters were recorded before the first and the last milking of the experimental period. Milk parameters were measured at 24- and 14-h milking intervals for $\times 1$ and $\times 2$ goats, respectively.

${ }^{3} \mathrm{UD}=$ udder depth; $\Delta \mathrm{CF}=$ difference between initial and final cistern-floor $(\mathrm{CF})$ distance; $\Delta \mathrm{TF}=$ difference between initial and final teat-floor (TF) distance.

${ }^{4} \mathrm{~B}=$ breed; $\mathrm{F}=$ milking frequency.

with observations in dairy cows by Waldmann et al. (1999) and dairy ewes by McKusick et al. (2002).

Milk protein percentage was unaffected by milk partitioning (Table 1). This agrees with observations in dairy ewes by McKusick et al. (2002) and dairy cows by Ayadi et al. (2004), indicating that casein micelles passed more freely than fat globules from the alveolar to the cisternal compartment between milkings, resulting in minimal differences in protein concentration of milk fractions.

Lactose content in cisternal milk was not affected by milking frequency (Table 1). Lactose content in alveolar milk in Majorera and Tinerfeña breeds was not different between $\times 1$ and $\times 2$ goats, whereas in the Palmera breed, lactose content was lower for $\times 1$ goats $(P<0.05)$. The decrease in milk lactose percentage seems to be due to lactose passing from milk into blood through an impaired tight junction (Stelwagen et al., 1994) associated with extended milking intervals.

The results for the SCC showed that Tinerfeña goats presented higher values than Majorera and Palmera goats for $\times 1$. Nevertheless, no differences in SCC level were found for $\times 2$ between the studied breeds (Table 1). Harmon (1994) indicated that variability in SCC within a breed is greater than variability in SCC be- tween breeds; therefore, it is possible that the results found could be due to an effect of individual variability.

Milking frequency did not affect the milk SCC. No coincident data exist about the effect of milking frequency on SCC levels. Salama et al. (2003) did not find significant differences in SCC between $\times 1$ and $\times 2$ goats in 32 Murciano-Granadina goats during an entire lactation, whereas Komara et al. (2009) conducted 2 experiments with Alpine goats and found differences only in experiment 1 , which could be due to the different number of goats used in each experiment (48 for experiment 1 and 8 for experiment 2) and to individual variability, as indicated by the authors.

No udder halves presented clinical mastitis during the experimental period, suggesting that $\times 1$ does not impair udder health and indicating that the breeds are fully adapted to this milking frequency. Lacy-Hulbert et al. (2005) did not report differences in the number of clinical or subclinical infections between $\times 1$ and $\times 2$ in dairy cows. Nudda et al. (2002) suggested that high SCC levels induced by a change in milking frequency may be temporary and not necessarily due to mammary gland infections.

In conclusion, the fact that about $80 \%$ of total milk was stored in cisternal compartments for 14- and 24-h 
milking intervals suggested a greater transfer of milk from the alveoli to the cistern during early udder filling and, therefore, did not produce significant changes in the milk composition. However, milking intervals caused diverse changes in the milk composition in the alveolar fraction, especially in fat, lactose, and TS contents; therefore, it merits further investigation of the mechanisms responsible for milk ejection between milkings.

\section{ACKNOWLEDGMENTS}

This work was supported by Fondo Europeo de Desarrollo Regional-Instituto Nacional de Investigación y Tecnología Agraria y Alimentaria (FEDER-INIA) RTA2009-00125.

\section{REFERENCES}

Ayadi, M., G. Caja, X. Such, and C. H. Knight. 2003. Use of ultrasonography to estimate cistern size and milk storage at different milking intervals in the udder of dairy cows. J. Dairy Res. 70:1-7.

Ayadi, M., G. Caja, X. Such, M. Rovai, and E. Albanell. 2004. Effect of different milking intervals on the composition of cisternal and alveolar milk in dairy cows. J. Dairy Res. 71:304-310.

Bruckmaier, R. M., G. Paul, H. Mayer, and D. Schams. 1997. Machine milking of Ostfriesian and Lacaune dairy sheep: Udder anatomy, milk ejection and milking characteristics. J. Dairy Res. 64:163172.

Capote, J., A. Argüello, N. Castro, J. L. López, and G. Caja. 2006. Correlations between udder morphology, milk yield and milking ability with different milking frequencies in dairy goats. J. Dairy Sci. 89:2076-2079.

Harmon, R. J. 1994. Physiology of mastitis and factors affecting somatic cell counts. J. Dairy Sci. 77:2103-2112.

Jarrige, J. 1990. Alimentación de bovinos, ovinos y caprinos. 1st ed. Mundi-Prensa, Madrid, Spain.

Knight, C. H., and R. J. Dewhurst. 1994. Once daily milking of dairy cows: Relationship between yield loss and cisternal milk storage. J. Dairy Res. 61:441-449.
Komara, M., M. Boutinaud, H. Ben Chedly, J. Guinard-Flament, and P. G. Marnet. 2009. Once-daily milking effects in high-yielding alpine dairy goats. J. Dairy Sci. 92:5447-5455.

Lacy-Hulbert, S. J., D. E. Dalley, and D. A. Clark. 2005. The effects on once a day milking on mastitis and somatic cell count. Proc. N.Z. Soc. Anim. Prod. 65:137-142.

López, J. L., J. Capote, G. Caja, S. Peris, N. Darmanin, A. Argüello, and X. Such. 1999. Changes in udder morphology as a consequence of different milking frequencies during first and second lactation in Canarian dairy goats. Pages 100-103 in Milking and Milk Production of Dairy Sheep and Goats. F. Barillet, and N. P. Zervas, ed. Wageningen Pers, Wageningen, the Netherlands.

McKusick, B. C., D. L. Thomas, Y. M. Berger, and P. G. Marnet 2002. Effect of milking interval on alveolar versus cisternal milk accumulation and milk production and composition in dairy ewes. J. Dairy Sci. 85:2197-2206.

Nudda, A., R. Bencini, S. Mijatovic, and G. Pulina. 2002. The yield and composition of milk in Sarda, Awassi, and Merino sheep milked unilaterally at different frequencies. J. Dairy Sci. 85:2879-2884.

Peaker, M. 1980. The effect of raised intramammary pressure on mammary function in the goat in relation to the cessation of lactation. J. Physiol. 301:415-428.

Salama, A. A. K., G. Caja, X. Such, S. Peris, A. Sorensen, and C. H. Knight. 2004. Changes in cisternal udder compartment induced by milking interval in dairy goats milked once or twice daily. J. Dairy Sci. 87:1181-1187.

Salama, A. A. K., X. Such, G. Caja, M. Rovai, R. Casals, E. Albanell, M. P. Marín, and A. Martí. 2003. Effects of once versus twice daily milking throughout lactation on milk yield and milk composition in dairy goats. J. Dairy Sci. 86:1673-1680.

Stelwagen, K., S. R. Davis, V. C. Farr, C. G. Prosser, and R. A. Sherlock. 1994. Mammary epithelial cell tight junction integrity and mammary blood flow during an extended milking interval in goats. J. Dairy Sci. 77:426-432.

Waldmann, A., E. Ropstad, K. Landsverk, K. Sørensen, L. Sølverød, and E. Dahl. 1999. Level and distribution of progesterone in bovine milk in relation to storage in the mammary gland. Anim. Reprod. Sci. 56:79-91.

Wellnitz, O., R. M. Bruckmaier, C. Albrecht, and J. W. Blum. 1999. Atosiban, an oxytocin receptor blocking agent: Pharmacokinetics and inhibition of milk ejection in dairy cows. J. Dairy Res. $66: 1-8$. 